\title{
Affective Reactions Among Students Belonging to Ethnic Groups Engaged in Prior Conflict
}

\author{
Neila Ramdhani, ${ }^{1}$ Haidar Buldan Thontowi, ${ }^{2}$ and Djamaludin Ancok ${ }^{3}$ \\ ${ }^{1}$ Faculty of Psychology, Universitas Gadjah Mada, Yogyakarta, Indonesia \\ 2 Faculty of Psychology, Universitas Gadjah Mada, Yogyakarta, Indonesia \\ 3 Faculty of Psychology, Universitas Gunadarma, Depok, Jakarta, Indonesia
}

\begin{abstract}
Thes he study aimed at investigating any bias in the perceptions of young people from two ethnic groups who were not directly involved in an ethnic conflict. Assuming that such perception bias only happens in the members of ethnic groups who were involved in the conflict and in those who became the victims of the other group's transgression. Therefore, we predicted that the subjects from the Dayaknese group would evaluate the photos of their own group members more positively compared to their perception of the Madurese photos. Meanwhile, there would be no bias among Madurese students in evaluating both Dayak and Madura photos. An experimental approach was carried out using photos of neutral faces of Dayaknese and Madurese people. Each photo was presented with negative or positive words. The participants of the study comprised 111 students who represented Madurese and Dayaknese ethnic groups, as well as Javanese who had not been involved in the conflict serving as the control group. They were asked to evaluate the photos in terms of the negativity and positivity of each picture. A two-way ANOVA supported the hypothesis that the Dayaknese evaluated their own groups better than the other ethnic groups, while the Madurese did not.
\end{abstract}

Keywords: ethnic conflict, emotion, in-group, out-group, group bias

It is difficult to separate conflict from the aspect of emotion. Conflict inherently entails the exchange of negative emotions between individuals or groups. Negative emotions not only appear at the cognitive level but also lead to negative emotions towards other persons or groups. In extreme cases, these negative emotions may result in behaviours of confrontation or attack towards a specific target person or group, and produce deeply apprehensive consequences. Since common experiences, shared norms, and the socialisation process lead to the formation of collective emotional orientation (Kitayama \& Markus, 1994), individual conflict may develop into a collective emotional orientation (Jarymowicz \& Bar-Tal, 2006).

Considering the importance of emotions, in the current study we investigated whether negative emotions continue to linger between members of ethnic groups who had once engaged in a violent conflict. The current study was expected to contribute to our understanding on how intergroup emotions caused by bloody conflicts influenced the perceptions of younger generation students who share the ethnic identities of the conflicting parties but were not directly involved in the conflict itself.

\section{Conflict Theories in Psychology: Emotions Theory on the Rise}

Addressing conflict unequivocally requires discussions about the relation between the conflicting parties. One of the earliest theories employed to study intergroup threat was realistic group conflict theory (RGCT). It proposed that negative out-group attitudes were a result of competition for scarce resources (Sherif \& Sherif, 1969). Symbolic threat theory was subsequently proposed to explain negative attitudes towards out-groups in the absence of competition for scarce resources (Kinder \& Sears, 1981). This approach asserted that intergroup bias resulted from conflicting values and beliefs rather than from competition or conflicting goals. Integrated threat theory acknowledged the merits of both the realistic threat and symbolic threat theories and therefore asserted that both these threats complemented each other to increase negative attitudes towards an out-group (Stephan \& Stephan, 2000).

During the last decades, researchers have developed their interest in intergroup relations and how this relates with emotions (Giner-Sorolla, Mackie, \& Smith, 2007; Iyer \& Leach, 2008). More specifically, researchers have suggested that emotions are not only experienced at the

Address for correspondence: Neila Ramdhani, Faculty of Psychology, Universitas Gadjah Mada, Yogyakarta, Indonesia. Email: neila_psi@ugm.ac.id 
individual level but also at the group level, a phenomenon termed intergroup emotion (Smith, Seger, \& Mackie, 2007). This theory asserts that the salience of a social distinctive identity, such as ethnicity, religious and political affiliation, might produce specific emotional states that differ from an individual's personal emotional experience.

Intergroup emotion differs from an individual's personal emotion, the strength of which depends on the person's level of identification with a particular social group. Intergroup emotions are socially shared within a group and contribute to the regulation of in-group and intergroup attitudes and behaviours. With regard to intergroup conflict, most importantly, a group's level of emotions can predict attitudes and behavioural intentions towards outgroups. A group's anger at an out-group and its positive emotions towards an in-group are the strongest predictors for confronting and avoiding the out-group (Smith et al., 2007). Gaining support from members of an ingroup can also make group members more willing to argue with, confront, oppose, and attack the out-group (Mackie, Devos, \& Smith, 2000). Furthermore, unsatisfactory retaliation following the experience of intergroup anger may result in increased desire to retaliate (Maitner, Mackie, \& Smith, 2006). However, future desire for intergroup aggression will be reduced if in-group members of a perpetrator group feel a strong sense of guilt compared with those with low guilt (Maitner, Mackie, \& Smith, 2007).

Intergroup emotions, in addition to being able to predict aggressive tendencies towards a maligned out-group, also predict positive intergroup relations. The feeling of regret of a transgressing group reduces the desire for retribution, while its absence increases it (Leonard, Mackie, \& Smith, 2011). Social categorisation of a group also influences the level of intergroup anger directed at it; for example, using a general overarching social category, American students were led to self-categorise as Americans or as students, and reported their anger and respect towards Muslims. When subjects were categorised as students, they reported more respect and less anger towards Muslims than when categorised as Americans (Ray, Mackie, Rydell, \& Smith, 2008).

The researchers observed the merits of this theoretical framework to address the topic of conflict management. The theories suggest that intergroup emotions may endorse particular behaviours that implicate the dissipation or the perpetuation of a conflict. Therefore, we used our understanding of the theories above to comprehend one of the conflicts occurring in Indonesia between the Madurese and Dayaknese ethnic groups.

\section{Madurese Versus Dayaknese Conflict}

As people seek new opportunities, a better standard of living, or escape the land due to persecution, migration becomes a viable alternative to achieve such goals of selfsufficiency. Unfortunately, in some cases, migrants' suc- cess in grasping economic opportunities comes at the cost of the indigenous people's welfare. It is in this context that intergroup conflict between the hosts and migrants becomes inevitable, and such was the case between the Madurese and the Dayaknese in Kalimantan, Indonesia, which fuelled wide-scale ethnic conflicts, beginning from 1996 and recurring until the year 2001. The magnitude of the conflict cannot be underestimated; the last incidence of mass violence in 2001 reportedly had an estimated death toll of 500 people, mostly from the Madurese ethnic group, when most of them were expelled from the province, and victims were butchered and decapitated using machetes (Achwan, Nugroho, Prayogo, \& Hadi, 2005). Although by $2005,80 \%$ of the displaced Madurese returned to some areas of Central Kalimantan, it remained strictly closed for the Madurese to enter other areas of Kalimantan.

It has been more than a decade since the bloody conflict in Kalimantan, and the researchers in this study were interested in how the members of both ethnic groups felt about each other; that is, how Dayaknese people felt about Madurese people and vice versa. Did both ethnic groups still hold their anger towards each other? Baumeister, Bratslavsky, Finkenauer, and Vohs (2001), who studied several researches concerning emotions, reported that negative emotions are more strongly imprinted than positive ones. This conclusion was strengthened by an analysis of various theories (Rozin \& Royzman, 2001) that suggested that negative entities have stronger valence than positive ones. It also came to the attention of Sander and Scherer (2009), who stated that negative attitudes about unpleasant stimulus were shaped with single-trial learning only and were difficult to erase. On the other hand, it took longer to develop positive attitudes. Therefore, individuals tended to be more sensitive towards negative entities than towards positive ones.

Furthermore, Hoffman (1982) proposed that guilt encourages reparative behaviours and increases motivation to communicate with the victims. In the case of the conflict between Dayaknese and Madurese, it was assumed that the Madurese were the group who conducted transgression behaviours such as occupying lands and taking employment and business opportunities from the Dayaknese people. Assuming that young members of every ethnic group have the same cognitive structure as their predecessors as a result of the process of social interaction and collectively shared communication (Augoustinos \& Innes, 1990), we therefore conceived that the younger generation of Madurese who lived on other islands experienced the same feelings about their ancestors' behaviours, especially in the context of Indonesia, where ethnicity is a salient issue. In order to reduce this guilt, it was predicted that the younger generation of Madurese would compensate for their guilt by perceiving Dayaknese people in a more positive way. This corresponds with cognitive dissonance theory (Breslavs, 2013; Festinger, 1962), where people reduce the feeling of dissonance by changing their 
cognition. To the best of our knowledge, there has been no study to test this argument in the context of intergroup conflict.

In this study, we tried to provide the answer to this question by intentionally focusing on investigating the younger generation of both ethnic groups who did not directly experience the bloody conflict. In addition, we included a Javanese ethnic group who were not involved in the conflict between Dayaknese and Madurese. This group does not affiliate with either Dayaknese or Madurese people. Therefore, we predicted that Javanese would perceive both groups in a similar way.

Furthermore, we hypothesised that this study would provide further support for the intergroup emotion theory. The theory posits that people who identify with a group should feel similar emotions with other group members when their social identity is salient. In this case, we tested whether this notion was applicable to people of the Dayak and Madura ethnic groups who did not reside in the area of conflict. Based on the argument proposed by Augoustinos and Innes (1990), that young members of ethnic groups can have the same cognitive structure as their predecessors, we assumed that intergroup emotions should be similar for group members when their ethnic identity is salient, regardless of where they live.

In conducting this preliminary study, we collected data from Dayaknese and Madurese students who were living in Yogyakarta, a city in Java island far away from the islands of Kalimantan and Madura. Although the conflict occurred in Kalimantan, intergroup emotion theory posits that people who are related to a social identity elicit specific intergroup negative emotions when their ethnic groups are subjected to unjust assault and positive emotions when they are favoured. We assumed that such perception bias will happen in the members of ethnic groups who are involved in a conflict and in those who become the victims of the other group's transgression. Bias will not happen in the ethnic groups' members who perceive their own group members as the perpetrators. Based on this assumption we predicted that: (1) The subjects from the Dayaknese group would evaluate the photos of their own group members more positively compared to their perception of the photos of the Madurese. (2) There would be no bias in the perception of the Madurese of the photos of their own group and other group members, when either photos were paired with positive or negative words. This prediction was based on the assumption that subjects from the Madurese group experienced guilty feelings due to their parents being considered as the perpetrators, such as by taking resources (e.g., land, job opportunities) from the Dayaknese people. These guilty feelings need to be compensated by evaluating the Dayaknese in a more positive way. (3) There was no group bias in the perception of Javanese students of the photos of the Madurese or Dayaknese people, both for negative and positive words.

\section{Methods}

\section{Participants}

The participants in the study consisted of students studying in Yogyakarta who represented three ethnic groups, namely Madurese, Dayaknese, and Javanese. The Madurese and Dayaknese ethnic groups were chosen to represent the groups engaged in the conflict, while the Javanese group served as the control group who were not involved in the conflict. A total number of 111 students were involved in the study. They consisted of 39 Madurese, 35 Dayaknese, and 37 Javanese, comprising 83 males and 28 females. Their participation was voluntary and no monetary compensation was offered. Explicit informed consent was acquired from each participant before the data collection began. The study was approved by the Board of Ethic of the Faculty of Psychology, Gadjah Mada University.

\section{Materials Photo Stimulus}

To investigate the feelings students had about the Madurese and Dayaknese people, we used photographs that depicted Dayaknese and Madurese people in their traditional clothes. This ethnic identity, as shown by traditional dress, has been widely introduced to students through mandatory civic education books in primary school. More specifically, the participants viewed facial pictures of three men and three women from each ethnic group (six pictures per ethnic group). The stimulus expressing neutral emotions was presented in a $7.6 \times$ $12.6 \mathrm{~cm}$-sized photo in a booklet. The photos that were included in the study were selected from 18 photos from the preliminary study. Figures 1 and 2 are examples of the stimuli used in the study.

In the preliminary study, 18 photos of Dayaknese and Madurese people, consisting of five photos of male Dayaknese, five of female Dayaknese, five of male Madurese and three of female Madurese, were used. The people in the photos were young adults wearing traditional dress of their ethnic group. We did not measure to what degree the picture represented Dayaknese or Madurese. We believe the participants recognised the photos as either Dayaknese or Madurese because they knew both ethnic groups that were involved in the bloody conflict. In addition, the pictures of people from different ethnic groups in their traditional costumes have been introduced since elementary and junior high school through civic education. Therefore, we measured the neutrality of facial expression.

In the preliminary study, 30 psychology students were asked to evaluate the faces in the photos in term of neutrality of emotional expression using a 7-point scale. From the total of 18 photos, we selected photos that were rated as the most neutral (mean score of 3-5), while photos that were rated extremely (beyond means of 3-5) were discarded. 

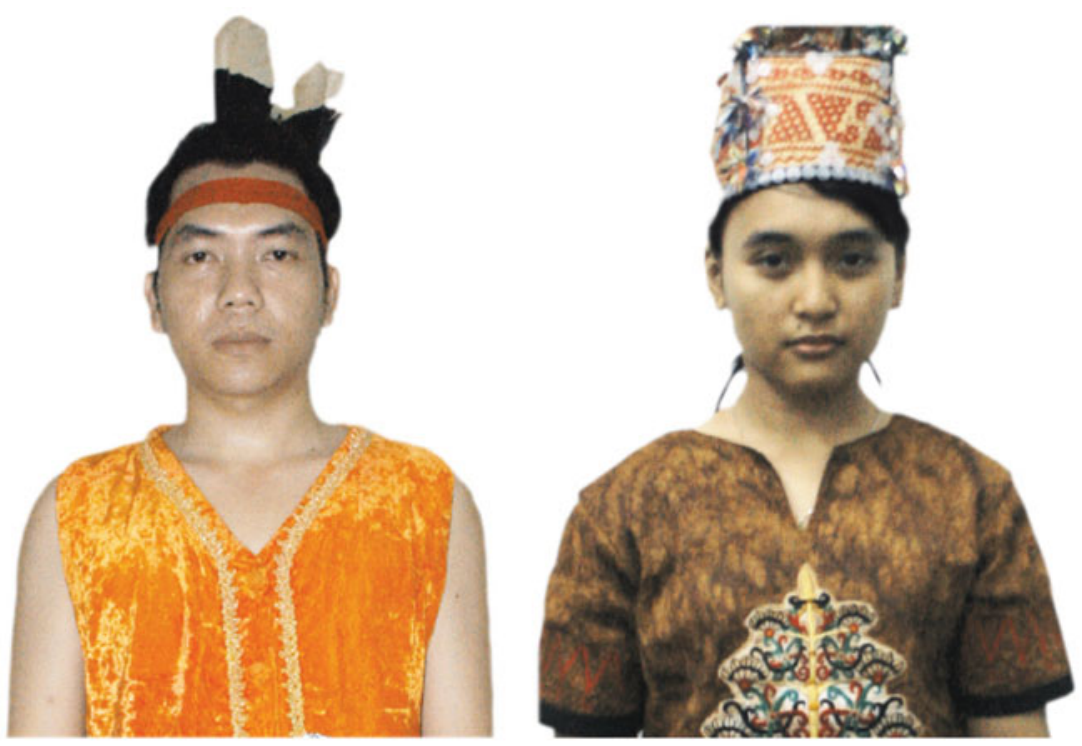

\section{Figure 1}

Male and female Dayaknese in traditional dress.
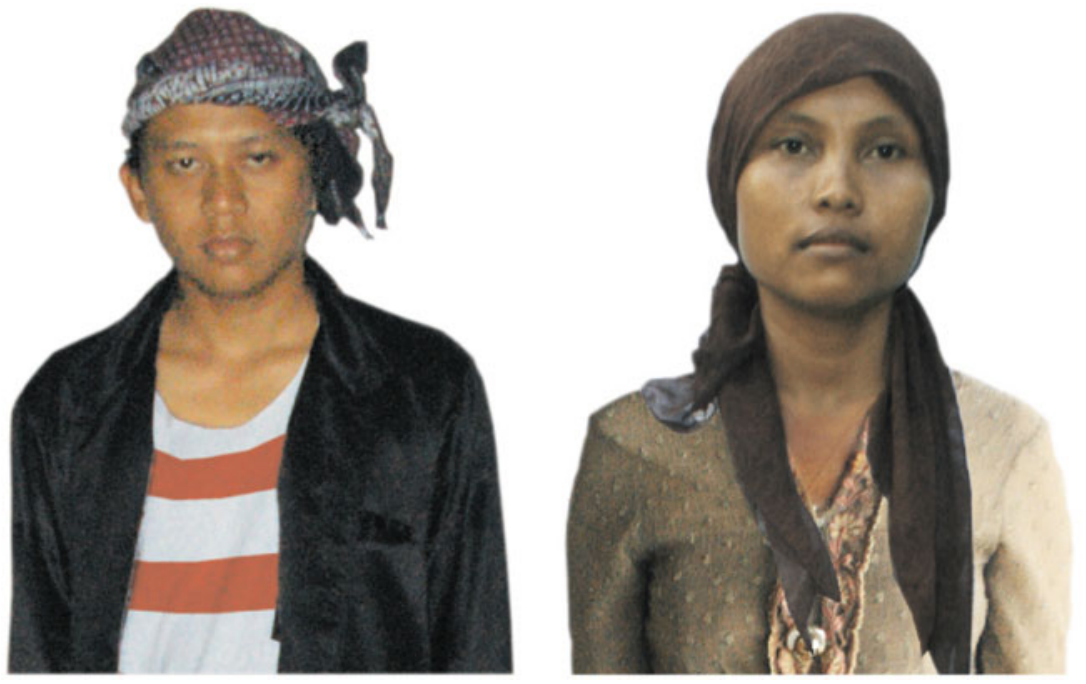

\section{Figure 2}

Male and female Madurese in traditional dress.

Selection of the photos resulted in three photos of male individuals and three photos of female individuals, as displayed below:

1. Photo of male Dayaknese $2($ mean $=4.1)$ with photo of male Madurese 3 (mean $=4.28$ ).

2. Photo of male Dayaknese $4($ mean $=3.78)$ with photo of male Madurese 4 (mean $=3.84)$.

3. Photo of male Dayaknese $1($ mean $=3.98)$ with photo of male Madurese 1 (mean $=4.38)$.

4. Photo of female Dayaknese $2($ mean $=3.67)$ with photo of female Madurese 3 (mean $=3.73$ ).

5. Photo of female Dayaknese $3($ mean $=3.35)$ with photo of female Madurese $1($ mean $=3.39)$.
6. Photo of female Dayaknese $4($ mean $=3.59)$ with photo of female Madurese $2($ mean $=3.76)$.

Under each photo, there was a list of words representing the participants' evaluation of the photo, whether positive (friendly, kind, helpful, happy) or negative (disgusting, suspicious, hateful, angry).

\section{Emotion Ratings}

The participants viewed each photo of either a Dayaknese or Madurese individual, and the question was asked: 'How do you feel when you see this photo? Please indicate your answer based on your actual feelings.' All aspects of the research were in line with American Psychological Association (APA) ethics guidelines. The participants' evaluations 
A Negative Evaluation

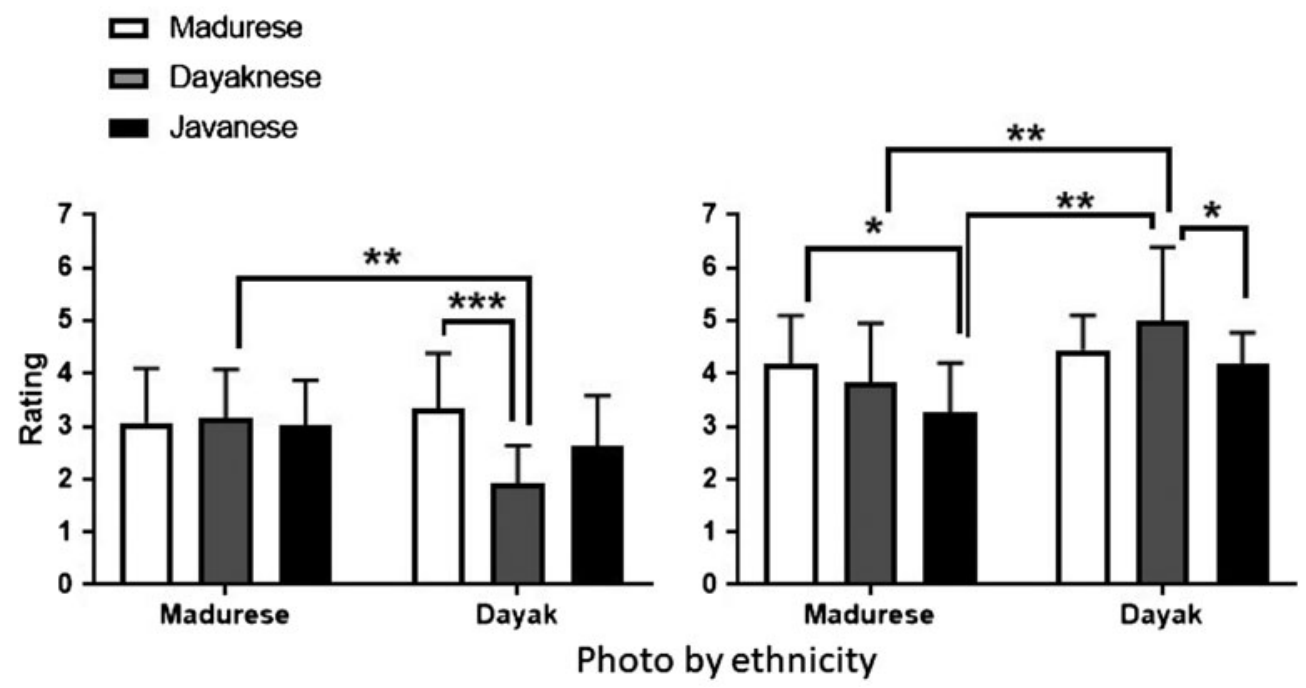

\section{B Positive Evaluation}

\section{Figure 3}

Affective evaluations of subject ethnicity by ethnic photo stimulus.

Note: ${ }^{*} p \leq .01,{ }^{* *} p \leq .05, * * * p=.00$.

of the photos were rated using a list of words consisting of four positive words (friendly, kind, helpful, happy), and four negative words (disgusting, suspicious, hateful, angry). The scale used a 7-point Likert format with scores ranging from 1 (strongly disagree) to 7 (strongly agree). Higher scores indicated ratings of high intensity and lower scores indicate low intensity of feelings. Scale reliability was adequate, shown by the alpha Cronbach value of 0.96 for the positive items and 0.95 for the negative items.

\section{Design}

The independent variable consisted of the students' ethnicities and photo stimulus. We used a $3 \times 2$ factorial design with three levels for the ethnicity factor (Dayaknese, Madurese, and Javanese), and two levels for the photo stimulus factor (Dayaknese and Madurese). The dependent variable consisted of ratings of positive and negative words.

\section{Results}

For the purpose of hypothesis testing, a multivariate analysis of variance (MANOVA) was run to analyse the responses of the respondents from the different ethnic groups (Madurese, Dayaknese, and Javanese) as the first factor and the ethnic photo stimulus (Dayaknese and Madurese) as the second factor, with positive and negative emotions as the dependent variable.

\section{Ratings of Positive Evaluations Toward Photo Stimulus}

Significant main effects were evident for subject ethnicity, $F(2,105)=5.48, p=.005, \eta^{2}=0.09$, and photo stimulus, $F(2,105)=17.63, p=.000, \eta^{2}=0.14$. However, sig- nificant interaction effects between subject ethnicity and ethnic stimulus were not found, $F(2,105)=2.19, p=.12$, $\eta^{2}=0.04$.

With regard to positive evaluation, based on the result of the post hoc comparison, the Dayaknese students rated the Dayaknese photos (see Figure 3B), significantly more positively $(M=4.99, S D=1.39)$ than the Madurese photos $(M=3.83, S D=1.13)$. Interestingly, the Javanese students rated the Madurese photos less positively $(M=3.26, S D=$ $0.94)$ than their evaluation of the Dayaknese photos $(M=$ $4.17, S D=0.60)$. However, the Madurese students' evaluation of the Madurese and Dayaknese photos was not significantly different.

The results of the simple effects analysis indicated differences in both ratings of Madurese, $F(2,105)=4.54$, $p=.01, \eta^{2}=0.08$, and Dayaknese photos, $F(2,105)=$ $3.38, p=.04, \eta^{2}=0.06$. Post hoc comparison using Tukey HSD test indicated that Madurese photos were significantly rated more positively by Madurese students $(M=$ $4.19, S D=0.91)$ compared to the ratings given by Javanese subjects $(M=3.26, S D=0.94)$. However, evaluations by the Dayaknese students $(M=3.83, S D=1.13)$ were not significantly different compared to the Madurese and Javanese students' evaluation. For the Dayaknese photos, we only found a significant difference between the positive evaluation of Dayaknese students $(M=4.99, S D=$ $1.41)$ and the Javanese students $(M=4.16, S D=0.62)$.

Similar comparisons were done for the ratings given to the Dayaknese photos. The Dayaknese photos were rated most positively by the Dayaknese students, followed by the evaluation by the Madurese subjects, and finally by Javanese subjects. Interestingly, post hoc comparison showed that evaluations by Javanese participants 
$(M=4.17, S D=0.60)$ were low and significantly different when compared to the evaluations done by the Dayaknese students $(M=4.99, S D=1.39)$ and the Madurese students $(M=4.45, S D=0.65)$. However, the evaluations by the Dayaknese and Madurese of the Dayaknese photos were not significantly different.

Simple effects analysis of the ethnic groups' independent ratings of Madurese and Dayaknese photos was also conducted. Differences were evident for the Dayaknese, $F(1,105)=12.49, p=.001, \eta^{2}=0.11$, and Javanese, $F(1$, $105)=8.1, p=.005, \eta^{2}=0.07$, student ratings of the photos, while differences for the Madurese were not found, $F(1,105)=0.67, p=.42, \eta^{2}=0.00$. More specifically, the Dayaknese rated the Dayaknese photos more positively ( $M=4.99, S D=1.39)$ compared to the Madurese photos $(M=3.83, S D=1.13)$. The Javanese also rated the Dayaknese more positively $(M=4.17, S D=0.6)$ than the Madurese photo $(M=3.26, S D=0.94)$.

\section{Ratings of Negative Evaluations Towards Photos of the Dayaknese and Madurese}

The MANOVA analysis for negative words indicated a significant main effect for the ethnicity, $F(2,105)=4.78$, $p=.01, \eta^{2}=0.08$, and photo stimulus, $F(1,105)=6.57$, $\mathrm{p}=.01, \eta^{2}=0.06$. These two main effects were qualified by a significant two-way interaction between ethnicity and photo stimulus, $F(2,105)=6.24, p=.003, \eta^{2}=0.1$.

Simple effect analysis was subsequently conducted to observe the results of ethnic photo stimulus interaction. The results indicated differences in the ratings of the Dayaknese photos, $F(1,105)=11.56, p=.00, \eta^{2}=0.2$, but not for the ratings of the Madurese photos, $F(1,105)=$ $.11, p=.89, \eta^{2}=0.00$ (Figure 3A). Accordingly, post-hoc comparisons using the Tukey HSD test indicated that the Madurese rated the Dayaknese photos $(M=3.3, S D=$ 1.05) significantly higher than the Dayaknese $(M=1.91$, $S D=0.73)$. Meanwhile, ratings by the Javanese $(M=2.64$, $S D=0.95)$ did not significantly differ compared to the ratings given by the Madurese and Dayaknese.

Furthermore, a simple effect analysis was conducted to observe differences between ethnic groups' independent ratings of Madurese and Dayaknese photos. Differences were evident for the Dayaknese students' ratings of the photos, $F(1,105)=15.87, p=0.00, \eta^{2}=0.13$, but not for the Madurese, $F(1,105)=.85, p=0.36, \eta^{2}=0.00$, or Javanese students $F(1,105)=1.53, p=0.22, \eta^{2}=0.01$. More specifically, post hoc comparisons showed that Dayaknese subjects rated the Madurese photos significantly more negatively $(M=3.16, S D=0.91)$ compared to their evaluations of the Dayaknese photos $(M=1.91, S D=0.73)$. However, the evaluations done by the Madurese and Javanese students of the photos of the Madurese and Dayaknese were not different. When observing affective reactions towards the Dayaknese photos only, we also found that the Dayaknese students reported significantly fewer negative evaluations $(M=1.91, S D=0.73)$ compared to the Madurese students $(M=3.34, S D=1.04)$. Therefore, it could be said that the bias among these groups existed in the Dayaknese only. These findings are in line with our hypothesis that Madurese students would show no bias in favour of their own ethnic group.

\section{Discussion}

The current study hypothesised that (1) the subjects from the Dayaknese group would evaluate the photos of their own group members more positively compared to their perceptions of the photos of the Madurese; and (2) there would be no bias in the perception of the Madurese towards the photos of their own group and other group members, whether the photos were paired with positive or negative words.

\section{Negative and Positive Emotion Ratings of Dayaknese and Madurese Photos}

Did every photo stimulus have an effect on Dayaknese, Madurese, and Javanese students' ratings? Apparently the photos were strong enough to elicit varying emotional ratings between the groups. For both positive and negative words, the photos did affect the raters' responses based on ethnicity, and this was indicated by the significant main effect of photo stimulus on ratings of positive and negative evaluations. Consistent with our predictions, ingroup bias was evident with Dayaknese students' ratings. In the case of photos with positive words, the Dayaknese students evaluated the Dayaknese photos more positively compared to their evaluation of Madurese photos. In the case of the photos with negative words, the Dayaknese students rated the Madurese photos more negatively compared to their evaluation of Dayaknese photos. In contrast, the Madurese students showed no significant difference in the way they evaluated Dayaknese photos and Madurese photos for both positive or negative words. These results supported the hypothesis that bias in favour of an in-group would only happen in the Dayaknese students, but not in the Madurese students.

The findings confirmed the suggestions of intergroup emotion theory that intergroup emotions are socially shared within a group (Smith et al., 2007). The conflict between the Dayaknese and Madurese groups occurred in early 2000 and did not involve any of the students in the study. It has been more than a decade since the event. However, we found that displaying photos of an out-group elicited both positive and negative words, which reflected in-group favouritism and out-group derogation.

\section{Javanese Ratings Towards the Madurese Photos}

In order to test our hypothesis, we included Javanese students as the control group, considering that this ethnic group is distant from the location of the conflict and is culturally distinct from both the Dayaknese and Madurese groups. We predicted that Javanese students would evaluate the photos of both ethnic groups in a similar way for both negative and positive evaluations. Surprisingly, 
inconsistent results were shown by the Javanese students. They gave different ratings when they were shown photos with positive and negative words. For positive words, they perceived the photos of the Dayaknese more positively compared to the photos of the Madurese. However, there was no difference in the way Javanese perceived the photos of both ethnicities for negative words. One possible reason for this result is a feeling of empathy towards the victims (Batson et al., 1997; Eisenberg, Eggum, \& Giunta, 2011). In the case of conflict between Dayaknese and Madurese, Madurese students may perceive Dayaknese as the victims of the transmigration program. The Madurese as migrants inhabited the lands of the Dayaknese and enjoyed the available resources and business opportunities there. This is in line with the assumption of the cognitive dissonance theory (Breslavs, 2013; Festinger, 1962), where people reduce feelings of dissonance by changing their cognition. The students in the study already knew that the conflicts between Dayaknese and Madurese had been widely published in media, and that the conflicts had been ongoing.

\section{Limitations and Future Research}

There were three limitations of this study. First, to what degree subjects identify themselves as an ethnic group involved in conflicts was not measured. In this study, we assumed that students identified with their own ethnic group through watching pictures of ethnic groups involved in conflicts. Second, the assumption that Madurese students perceive the Dayaknese as victims in the transmigration program was not directly measured in this study. Finally, the sample in the study cannot be assumed to represent the attitudes of all Madurese, Dayaknese, and Javanese, considering that the data collection did not use a randomised sampling scheme. Further research on this topic should investigate these unmeasured variables and collect data from a representative sample using a rigorous sampling scheme.

\section{References}

Achwan, R., Nugroho, H., Prayogo, D., \& Hadi, S. (2005). Overcoming violent conflict: Peace and development analysis in West Kalimantan, Central Kalimantan and Madura. Jakarta, Indonesia: Crisis Prevention and Recovery Unit (CPRU), LabSosio and BAPPENAS.

Augoustinos, M., \& Innes, J.M. (1990). Towards an integration of social representations and social schema theory. British Journal of Social Psychology, 29, 213-231.

Batson, C.D., Polycarpou, M.P., Harmon-Jones, E., Imhoff, H.J., Mitchener, E.C., Bednar, L.L., ... Highberger, L. (1997). Empathy and attitudes: can feeling for a member of a stigmatized group improve feelings toward the group? Journal of Personality and Social Psychology, 72, 105-118. https://doi.org/10.1037/0022-3514.72.1.105

Baumeister, R.F., Bratslavsky, E., Finkenauer, C., \& Vohs, K.D. (2001). Bad is stronger than good. Review of General Psychology, 5, 323-370. https://doi.org/10.1037//1089-2680.5.4.323
Breslavs, G.M. (2013). Moral emotions, conscience, and cognitive dissonance. Psychology in Russia: State of the Art, 6, 65-72.

Eisenberg, N., Eggum, N.D., \& Giunta, L. Di. (2011). Empathyrelated responding: Associations with prosocial behavior, aggression, and intergroup relations. Social Issues and Policy Review, 4, 143-180. https://doi.org/10.1111/ j.1751-2409.2010.01020.x

Festinger, L. (1962). A theory of cognitive dissonance ( vol. 2). Palo Alto, CA: Stanford University Press.

Giner-Sorolla, R., Mackie, D.M., \& Smith, E.R. (2007). Special issue on intergroup emotions: Introduction. Group Processes \& Intergroup Relations, 10, 5-8. https://doi.org/ 10.1177/1368430206071661

Hoffman, M.L. (1982). Development of prosocial motivation: Empathy and guilt. In N. Eisenberg (Ed.), The Development of prosocial behavior (pp. 281-313). New York: Academic.

Iyer, A., \& Leach, C.W. (2008). Emotion in inter-group relations. European Review of Social Psychology, 19, 86-125.

Jarymowicz, M., \& Bar-Tal, D. (2006). The dominance of fear over hope in the life of individuals and collectives. European Journal of Social Psychology, 36, 367-392.

Kinder, D.R., \& Sears, D.O. (1981). Prejudice and politics: Symbolic racism versus racial threats to the good life. Journal of Personality and Social Psychology, 40, 414-431.

Kitayama, S.E., \& Markus, H.R.E. (1994). Emotion and culture: Empirical studies of mutual influence. Washington, DC: American Psychological Association.

Leonard, D.J., Mackie, D.M., \& Smith, E.R. (2011). Emotional responses to intergroup apology mediate intergroup forgiveness and retribution. Journal of Experimental Social Psychology, 47, 1198-1206.

Mackie, D.M., Devos, T., \& Smith, E.R. (2000). Intergroup emotions: Explaining offensive action tendencies in an intergroup context. Journal of Personality and Social Psychology, $79,602-616$.

Maitner, A.T., Mackie, D.M., \& Smith, E.R. (2006). Evidence for the regulatory function of intergroup emotion: Emotional consequences of implemented or impeded intergroup action tendencies. Journal of Experimental Social Psychology, 42, 720-728.

Maitner, A.T., Mackie, D.M., \& Smith, E.R. (2007). Antecedents and consequences of satisfaction and guilt following ingroup aggression. Group Processes \& Intergroup Relations, 10, 223237.

Ray, D.G., Mackie, D.M., Rydell, R.J., \& Smith, E.R. (2008). Changing categorization of self can change emotions about outgroups. Journal of Experimental Social Psychology, 44, 1210-1213. https://doi.org/10.1016/j.jesp.2008. 03.014

Rozin, P., \& Royzman, E.B. (2001). Negativity bias, negativity dominance, and contagion. Personality and Social Psychology Review, 5, 296-320.

Sander, D., \& Scherer, K. (2009). Oxford companion to emotion and the affective sciences. Oxford, UK: Oxford University Press. 
Sherif, M., \& Sherif, C.W. (1969). Ingroup and intergroup relations: Experimental analysis. In M. Sherif \& C.W. Sherif (Eds.), Social psychology (pp. 221-266). New York, NY: Harper \& Row.

Smith, E.R., Seger, C.R., \& Mackie, D.M. (2007). Can emotions be truly group level? Evidence regarding four conceptual criteria. Journal of Personality and Social Psychology, 93, 431446. https://doi.org/10.1037/0022-3514.93.3.431

Stephan, C.W., \& Stephan, W.G. (2000). What are the functions of ethnic identity. In We are a people: Narrative and multiplicity in constructing ethnic identity (pp. 229-243). Philadelphia, PA: Temple University Press. 